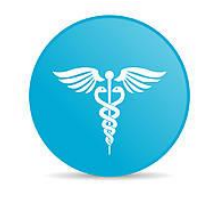

International Journal of Advances in Pharmacy and Biotechnology

Vol.4, Issue-1, 2018, 1-9

ISSN: 2454-8375

Review Article

I J A P B

Open Access

\title{
DRUG SAFETY ALERTS BY FDA AND CDSCO IN 2016: A RECENT REVIEW \& A STUDY OF ITS IMPLEMENTATION IN PRACTICE
}

\author{
Sulfath T S*, Amalu K, Neema J, Ms.Meby S M \\ *JSS college of Pharmacy, Bannimantap, Mysore, 570015. \\ *Corresponding author e-mail: Email id: tssulfath9@gmail.com
}

\begin{abstract}
Received: 8 January 2018
Revised: 23 January 2018

Accepted: 31January 2018

ABSTRACT:

Drug safety communication has evolved to provide the public with easy access to important drug safety information. This gives the most recent information for health care professionals. This study is a recent review of safety alerts from FDA \& CDSCO in the year 2016. The objective of this study was to review the most recent drug safety communications exhibited by FDA and CDSCO, the awareness of the same in community pharmacies and to determine its impact and implementation in practice. A review of fifteen drug alerts from 2016 by FDA and CDSCO was done. An observational community based study was conducted by making a questionnaire available to community pharmacists. The questionnaire consisted of 9 questions that evaluated the awareness, accessibility and importance of drug safety communication in practice. The study result denotes that none of the pharmacies have more than two drug information resources.
\end{abstract}

Key words: Drug safety communications, Drug safety alerts, FDA, CDSCO

\section{INTRODUCTION}

Drug safety communication was developed to provide the health care professionals and public with easy access to important and recent drug safety information. Drug safety alerts give authentic and updated safety announcements of various medications regarding their use, ADR and other toxic effects. A safety alert may include an approved change to the label, warnings to the health care professionals and patients regarding the use of medications. Warnings may include the unnoted drug interactions, contraindications in various diseased and other special populations, outweighed benefits over adverse effects, etc. This makes the awareness of safety alerts critical. FDA Food and drug administration and CDSCO Central drugs standard control organization, gives the recent updated information regarding the drugs, medical devices and other medical products used. They provide the announcements and alerts regarding the safety in using the drugs, where some cases are studied and reported from various sources. So their review has found to be relevant. The purpose is to prepare a recent review of drug alerts by FDA and CDSCO in the year of 2016. It also evaluates the awareness and availability of references for drug safety communications at the pharmacy and community level. A prospective, observational community based study was conducted by making a self administered questionnaire available for community pharmacists. The questionnaire consisted of 9 questions that evaluate the awareness, accessibility and importance of safety alerts in practice. [1] 


\section{METHODS}

The drug safety alerts were accessed through the links www.fda.gov, www.cdsco.nic.in, from which recent drug safety communications for the year 2016 were selected. The references for each alert were searched through the corresponding link. A prospective observational study on drug safety alerts and the importance of its implementation in practice was done to analyze the awareness, accessibility and usefulness of drug safety alerts among community pharmacists. A drug safety alert questionnaire as shown in Fig. 1 was prepared and data collected from 20 community pharmacies. The survey form comprised of five questions to collect the general information of a pharmacy, awareness and availability of references for drug safety alerts and methods used for professional quality development so as to be abrupt of current guidelines and measures to prevent adverse outcome in patients.

\begin{tabular}{|c|}
\hline \\
QRUG SAFETY ALERT \\
QUESTIONAIRE FORM \\
NIRMALA COLLEGE OF PHARMACY \\
Department of Pharmacy Practice
\end{tabular}

1. No. of qualified pharmacists:

2. No. of drug information resources available in pharmacy:

If so, mention: $\square$ Text form $\square$ E- resource

3. Are you aware of safe alerts? $\square$ Yes $\square$ No

If yes, name some resources used for reference at your pharmacy.

4. Have you identified safety alerts? $\square$ Yes $\square$ No

If yes, what actions have been taken to ensure adequate patient care?

5. Measures taken for professional quality development with date of activity last attended:

$\square$ Continuing Education Programme [Date

$\square$ Professional development course apart from degree/ diploma in pharmacy

[Date ]

$\square$ If so, mention course

[Date ]

Seminar [Date ]

Date and signature of pharmacist:

Fig. 1: Drug safety alert questionnaire form proforma 


\section{REVIEW OF LITERATURE FDA alerts}

Chantix (Varenicline) and Zyban (Bupropion) are used as stop smoking medicines. ${ }^{[3]}$ Anthenelli RM, Benowitz NL, West $\mathrm{R}$ found from a double blind, randomized, placebo-controlled clinical trial that $13(1-3 \%)$ of 990 participants reported moderate and severe neuropsychiatric adverse events in the vareniciline group, 22 $(2.2 \%)$ of 989 in the bupropion group and 24 (2.4\%) of 999 in the placebo group, 25 (2.5\%) of 1006 in the nicotine patch group. ${ }^{[4]}$ This made FDA to revise the description of mental health side effects of Zyban and Chantix and note outweighing benefits over risks of these medicines. FDA warns health care professional to counsel patients about the benefits of these stop smoking medicine.[5][6] Anasthetics and sedative drugs are necessary for infants, children and pregnant women who require surgery or other painful and stressful procedures. Based on the animal experiments done by Catherene E. Creely, the DIDNA and neurotoxicity in humans found to be caused by general anesthetics. According to ${ }^{[7,8]}$

Brambrink.AM et al, Back SA, Riddle A, Gong X, Moravec MD, Disen GA, Creely CE, Dikranian KT, Olney JW, reported that exposure of infant Rhesus macaque brain to general anesthetic isoflurane for 5 hrs cause neuronal apoptis in brain. These studies give the evidence of harm to the developing brain by general anesthetic. So FDA warns regarding the use of general anesthetic and sedative in young children and pregnant women since it can affect the brain development of children.[9][10]

As per the population based cohort study conducted by Tuccori M, Filion KB[11], $90.2 \%$ per $1,00,000$ persons per year were diagnosed with bladder cancer associated with plioglitazone use, an anti diabetic drug which increases insulin sensitivity. Cohort and nested case control analysis among persons with diabetes by Lewis JD, Habel LA, Quesentery $\mathrm{CP}^{[12]}$, suggest that pioglitazone use was associated with a statistically significant increased risk of bladder cancer. Hence, FDA cautions the health care professionals, not to use pioglitazone in patients with active bladder cancer and to be wary in those with a history of bladder cancer. Asked the patients to contact their health care professionals, if they experience any signs and symptoms after starting the drugs like blood or red color in urine, new or worsening urge to urinate, pain when urinating[13][14].

Opioids are used to treat pain and cough and Benzodiazepines are used to treat anxiety, insomnia and seizures. ${ }^{[15]}$ Jones CM, Mc Aninch JK studied that the concomitant prescribing opioids and benzodiazepines has been found to be increase from 11.0 to 34.2 per 1,00,000 population and drug overdose deaths increased from 0.6 to 1.7 per $1,00,000$. FDA review has found that the growing combined use of the 2 drugs depresses the CNS, slows breathing rate and causes death. Hence, FDA announced changes in the drug labeling and warns health care professionals and patients regarding its concomitant use. Fluoroquinolone antibiotics are a class of antibiotics used for wide range of infections, available in oral and injectable forms.[16] ÍMS, health vector one': TPT 2014, Extracted August 2015', In search of FAERS databases from November 1997 to May 2015, identified 178 U.S cases of disabling and potentially irreversible adverse reactions on using FQ to treat ABS, ABECB and uncomplicated UTI. This resulted FDA to update 'Boxed warning' with new limitations of use, side effects and precautions and suggest health care professionals to use non FQ in case of side effects shown by FQs.

Canagliflozin and Dapagliflozin are prescription medicines used with diet and exercise to help lower blood sugar in adults with type 2 DM.[17] ÍMS, health TPT, DATA 
2015-2308SGLT-2 inhibitor DSC.xlsx'. In search of FAERS databases from March 29 2013 to October 19 2015, identified 101 kidney injury cases with Canagliflozin and Dapagliflozin within one month of initiating the therapy. Four deaths occurred in which 2 with cardiac related problems. They also reviewed cases of ketoacidosis and serious UTI associated with use of SGLT-2 inhibitor. These reports influenced FDA to strengthen kidney warnings for diabetes medicines Canagliflozin (Invokana Invokamet) and Dapagliflozin (farxiga, Xigduo XR) and warns health care professionals to assess the kidney function prior to the use of drugs. [18-20] Loperamide (Imodium) is an antidiarrheal.[21] Jacqueline Argamany and Jennifer Seltzer reviewed the report of "American association of poison control centers national poison data system" from 2011-2014. Acute life threatening cardiac arrhythmias secondary to loperamide "mega doses were observed.[22] Spinner HL, Lonarde NW, Mulamalla R have presented a case of development of cardiac pauses, non sustained ventricular tachycardia with hemodynamic instability, after taking an entire bottle of Loperamide (144 mg) daily for 2 years. These cases lead FDA to warn health care professionals and patients regarding serious heart problems on abuse, misuse or overdose of Loperamide which can be controlled by following dosing recommendations on the label. OTC aspirin antacid products are used to treat heartburn, sour stomach, indigestion or stomach upset. A search of [23] FAERS database from January 1, 1969 to August 13, 2014 identified 41 cases of serious bleeding events reported with OTC aspirin- antacid products, resulted in hospitalization, required transfusions due to blood loss and one death. As a result FDA continues to evaluate this safety concern and want consumers to read "drug facts label" carefully on purchasing OTC products.

Zecuity patch is a prescription medicine containing the active ingredient
Sumatriptan used to treat acute migraine headaches in adults. From the marketing of Zecuity patch on September 2015, a large number of patients have reported the occurrence of burn, scars, severe redness, pain, skin discoloration, blistering and cracking of skin where the patch was worn. So FDA warns the patients to remove the patch as soon as they experience pain at the patch site, also not to take bathe, shower or swim while bearing the patch. Canagliflozin is an SGLT-2 inhibitor used with diet and exercise in Type- 2 diabetes. It is available as single drug product - Invocana and combination with Metformin - Invocamet. In ongoing risk of amputation for patients in the trial where equivalent to 7 out of 1000 patients treated with $100 \mathrm{mg}$ daily dose of Canagliflozin, 5 out of 1000 patients treated with $300 \mathrm{mg}$ daily dose of Canagliflozin and 3 out of 1000 patients treated with placebo. Hence FDA warns public about increased risk of leg and foot amputations with the Diabetes medicine Canagliflozin.

Olanzapine is an antipsychotic medicine used to treat mental health disorders. A search of FAERS database identified 23 cases of DRESS with Olanzapine. ${ }^{[23]}$ Out of which one was fatal case due to cardiac related problems, 18 required hospitalization and one recurrence of DRESS after Olanzepine rechallenge. Thus, FDA adds new warning for occurrence of DRESS in drug labels and warns health care professionals to stop Olanzepine if DRESS is suspected.

Aripiprazole is used to treat mental disorders. A search of FAERS database,[23] in November 2002 identified 184 case reports in which there was an association between aripiprazole use and impulse control problems. U.S cases include adult and children shows pathological gambling, compulsive eating, spending, sexual behavior, compulsive buying, multiple impulse control problem. Thus FDA warns about impulse 
control problems for Olanzapine use which are rare, but may result in harm to patient and others, if not recognized.

Oral Fluconazole is used to treat yeast infections of vaginal area, mouth and esophagus. ${ }^{[24]}$ Ditte Molgarard-Nelson, Henrik Svanstrom, Mads Melbyedone a cohort study in 1405663 pregnant women, compared unexposed- unmatched pregnant women with Fluconazole exposed pregnant women and found statistically significant increased risk of spontaneous abortion. Thus FDA warns health care professionals to treat vulvovaginal yeast infections in pregnant women using topical antifungal product instead of oral Fluconazole (Diflucan).[25-27] DAA medicines are used to treat HCV infection. These medicines prevents the multiplication of HCV in body.[28] Collins JM, Raphael KL, Tersy C, found HBV reactivates during successful treatment of HCV virus with Sofosbuvir and Simeprevir 2 DAAs in coinfected patients while conducting the case study. Also De Monte A, Courjon J, Anty R[29], reported the cases of early HBV reactivation during DAAs based anti-HCV treatment in patients having resolved HBV infection and chronically infected with HCV genotype4 and HIV. As a result, FDA announces a 'boxed warning' about the risk and warns patients to report regarding history of $\mathrm{HBV}$ infection or other liver problems to health care professionals before being treated for $\mathrm{HCV}$ infections.

\section{CDSCO drug safety alerts}

Till now CDSCO published safety alerts which include:

- Drugs banned in the country.

- Medical device and diagnostics alert.

- Order in respect of stop collection and sale of dendritic cells.

- Oxytocin drug alert

- Surveillance of drugs manufactured in the country by CDSCO.

- Substandard quality of human albumin I.P/E.P albumin solution for infusion.

- $\quad$ Spurious drugs.

- Drug alerts.

In the year of 2016, CDSCO has published the list of drugs, medical devices and cosmetics declared as "Not of standard quality/ Spurious/ Adulterated/ Misbranded", for each of 12 months. The name given in the list is the brand name along with the generic name, which specifies the brand which is not of standard quality/ spurious/adulterated/ misbranded. Few are listed below:

Table 1: List of drugs issued under CDSCO alerts in 2016

\begin{tabular}{|c|c|c|c|c|c|}
\hline S.No. & $\begin{array}{c}\text { Name of } \\
\text { drugs/medical } \\
\text { device/cosmetic }\end{array}$ & $\begin{array}{c}\text { Batch no of } \\
\text { manufacture / date } \\
\text { of expiry }\end{array}$ & $\begin{array}{c}\text { Reason } \\
\text { for failure }\end{array}$ & Drawn by & From \\
\hline 1 & $\begin{array}{c}\text { Oxyhars } \\
\text { (oxytocin inj.) }\end{array}$ & $\begin{array}{c}\text { B.No.: } 190 \text { G } 5 \\
\text { Mfg. dt.: 08/2015 } \\
\text { Exp. Dt.: 07/2017 } \\
\text { Mfd. by: M/s. Divine }\end{array}$ & $\begin{array}{c}\text { Particulate } \\
\text { matter }\end{array}$ & $\begin{array}{c}\text { CDSCO } \\
\text { Sub Zone } \\
\text { Ahmedabad }\end{array}$ & $\begin{array}{c}\text { C D L } \\
\text { Kolkata }\end{array}$ \\
\hline 2 & $\begin{array}{l}\text { Magnesium } \\
\text { sulphate } \\
\text { injection USP } \\
50 \%, 2 \mathrm{ml}\end{array}$ & $\begin{array}{c}\text { B.No.: MS-93 } \\
\text { Mfg. dt.: 06/2014 } \\
\text { Exp. Dt.: 05/2016 } \\
\text { Mfd. by: M/s. Rathi } \\
\text { Laboratories Pvt. Ltd. }\end{array}$ & $\begin{array}{l}\text { Volume } \\
\text { of } \\
\text { injection }\end{array}$ & $\begin{array}{l}\text { CDSCO } \\
\text { East } \\
\text { Zone, } \\
\text { Kolkata }\end{array}$ & $\begin{array}{c}\text { CDL } \\
\text { Kolkata }\end{array}$ \\
\hline
\end{tabular}




\section{RESULTS}

Various drug information resources available in pharmacies include textbook and E- resources and the data is presented in Table 2 and Fig. 2.

The analysis shows that none of the pharmacies have more than 2 resources available. The E-resources available are unpaid applications and the level of updated information obtained from such unpaid resources will be limited. Pharmacists in 9 pharmacies were aware of safety alerts and 11 were not as presented in Table 3 and Fig. 3.

Table 2: References available in pharmacies

\begin{tabular}{ccc}
\hline S.No. & Pharmacy reference criteria & No of pharmacies \\
\hline 1 & Text form only & 0 \\
\hline 2 & E- Resource only & 7 \\
\hline 3 & Both Text and E- Resources & 10 \\
\hline 4 & None & 3 \\
\hline
\end{tabular}

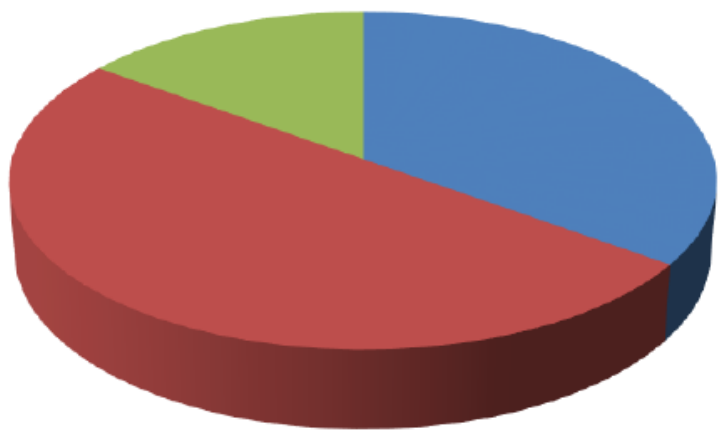

e-resource only

both text and e-resource

none

text form only

Fig. 2: References available in pharmacies

Table 3: Awareness of safety alerts

\begin{tabular}{ccc}
\hline S.No. & Criteria & No. of pharmacists \\
\hline 1 & Aware of safety alerts & 9 \\
\hline 2 & Not aware of safety alerts & 11 \\
\hline
\end{tabular}

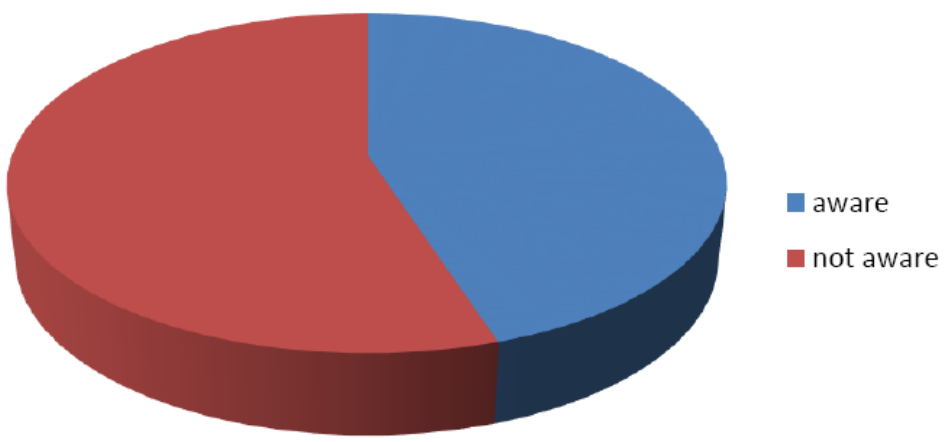

Fig. 3: Awareness of safety alerts 
A very few number of pharmacists are aware of safety alerts, none of them are aware of FDA \& CDSCO alerts. Pharmacists of 4 pharmacies included in survey only responded about the safety they have identified and the measures taken by them to ensure adequate patient care. Major part is unaware of the safety alerts and the recent updates about the medications. This can cause harmful effects in patients.

\section{DISCUSSION}

It is important for all health care professional to be aware of the drug safety alerts so that they can better render safer health care services. Patients will be benefited more, if the health care professionals are updating the changes and information regarding the use of medications. FDA and CDSCO release safety alerts based on the case reports, animal experiments and other study results reported to them. An alert may include an approved change to the label, warnings to the health care professionals and patients regarding the use of medications. Warnings may include the unnoted drug

\section{REFERENCES}

1. www.fda.gov

2. www.cdsco.nic.in

3. Anthenelli RM, Benowitz NL, West R, St Aubin L, McRae T, Lawrence D. Neuropsychiatric safety and efficacy of varenicline, bupropion, and nicotine patch in smokers with and without psychiatric disorders (EAGLES): a double-blind, randomised, placebo-controlled clinical trial. Lancet 2016; 387:2507-20.

4. National Cancer Institute; Harms of Cigarette Smoking and Health Benefits of Quitting; https://www.cancer.gov/ about-cancer/ causes-prevention /risk/ tobacco/ cessation-fact- sheet. Published December 3, 2014; Accessed: October 18, 2016.

5. Creeley C, Dikranian K, Dissen G, Martin L, interactions, contraindications in various diseased and other special populations, outweighed benefits over adverse effects, etc.. This makes the awareness of safety alerts critical.

\section{CONCLUSION}

From results of study it is evident that drug safety alerts are less known to the healthcare professionals. The knowledge of drug safety alerts helps the health care professionals to reduce the harmful effects of medications which may in turn benefit the patients.

\section{ACKNOWLEDGEMENT}

First and foremost, the authors sincerely thank "Almighty" for his grace for the successful publishing of the work. Authors are also profoundly grateful to Ms. Meby Susan Mathew, M.Pharm, Asst. Professor, Department of pharmacy Practice, Nirmala College of Pharmacy, Muvattupuzha for her excellent guidance, innovative ideas and immense help rendered at various stages of study.

Olney J, Brambrink A. Propofol-induced apoptosis of neurones and oligodendrocytes in fetal and neonatal rhesus macaque brain. Br J Anaesth 2013; 110 Suppl 1:i29-38.

6. Haberny KA, Paule MG, Scallet AC, Sistare FD, Lester DS, Hanig JP. Ontogeny of the $\mathrm{N}$-methyl-D-aspartate (NMDA) receptor system and susceptibility to neurotoxicity. ToxicolSci 2002; 68:9-17.

7. Creeley CE, Dikranian KT, Dissen GA, Back SA, Olney JW, Brambrink AM. Isofluraneinduced apoptosis of neurons and oligodendrocytes in the fetal rhesus macaque brain. Anesthesiology 2014; 120:626-38.

8. Brambrink AM, Back SA, Riddle A, Gong X, Moravec MD, Dissen GA. Isoflurane induced apoptosis of oligodendrocytes in 
the neonatal primate brain. Ann Neurol 2012; 72:525-35

9. Dormandy JA, Charbonnel B, Eckland DJ, Erdmann E, Massi-Benedetti M, Moules IK. Secondary prevention of macrovascular events in patients with type 2 diabetes in the PRO active Study (PROspective pioglitazone Clinical Trial In macroVascular Events): a randomised controlled trial. Lancet 2005; 366:127989.

10. Erdmann E, Harding S, Lam H, Perez A; Ten-year observational follow-up of PROactive: a randomized cardiovascular outcomes trial evaluating pioglitazone in type 2 diabetes. Diabetes ObesMetab 2016; 18:266-73

11. Tuccori M, Filion KB, Yin $\mathrm{H}, \mathrm{Yu} \mathrm{OH}$, Platt RW, Azoulay L.; Pioglitazone use and risk of bladder cancer: population based cohort study. BMJ 2016; 30;352:i1541

12. Lewis JD, Habel LA, Quesenberry CP, Strom BL, Peng T, Hedderson MM, et al.; Pioglitazone use and risk of bladder cancer and other common cancers in persons with diabetes. JAMA 2015; 314:265-77

13. Dasgupta N, Funk MJ, Proescholdbell $S$, Hirsch A, Ribisl KM, Marshall S.; Cohort Study of the Impact of High-dose Opioid Analgesics on Overdose Mortality. PubMed 2016;17:85-98.

14. Hwang CS, Kang EM, Kornegay CJ, Staffa JA, Jones CM, McAninch JK. Trends in the concomitant prescribing of opioids and benzodiazepines. Am J Prev Med 2016; 51:151-60.

15. Jones CM, McAninch JK. Emergency department visits and overdose deaths from combined use of opioids and benzodiazepines.; Am J Prev Med 2015; 49:493-501.

16. IMS Health, Vector One®: Total Patient Tracker (TPT), Y2014, Extracted AUG2015.

17. IMS Health, Total Patient Tracker (TPT);
DATA 2015-2308 SGLT2 Inhibitor DSC.xlsx.

18. O'Connell CW, Schricker AA, Schneir AB, Metushi IG, Birgersdotter- Green U, Minns AB.; High-dose loperamide abuse associated ventricular Arrhythmias; Heart Rhythm Case Reports. http://dx.doi.org/10.1016/j.hrcr.2016.01. 002

19. Sheyman J, Crake R.; Loperamide induced Brugada syndrome. Ohio Valley Medical Center Wheeling, WV Poster Presentation. February 2014.

20. Mukarram O, Hindi Y, Catalasan G, Ward J. Loperamide induced torsades de pointes: a case report and review of the literature.; Case Rep Me 2016; 2016:4061980

21. American Association of Poison Control Centers' National Poison Data System Annual Reports, 2006-2014.; http://www.aapcc.org/annual-reports/ Accessed February 1, 2016.

22. Spinner HL, Lonardo NW, Mulamalla R, Stehlik J. Ventricular tachycardia associated with high-dose chronic loperamide use Pharmacotherapy 2015; 35:234-238.

23. IMS Health: Vector One $\AA$ Total Patient Tracker (TPT). November 2002

24. Ditte Molgarard-Nelson, Henrik Svanstrom, Mads Melbye done a cohort study.

25. Ende AR, Kim NH, Yeh MM, Harper J, Landis CS. Fulminant hepatitis B reactivation leading to liver transplantation in a patient with chronic hepatitis $\mathrm{C}$ treated with simeprevir and sofosbuvir: a case report. J Med Case Rep 2015; 9:164.

26. Kimura H, Ohkawa K, Sakakibara M, Imanaka K, Matsunaga $\mathrm{T}$. Sustained hepatitis $\mathrm{C}$ virus RNA clearance accompanied by elevation of hepatitis $B$ virus DNA after short-term peginterferon-

27. Ribavirin and simeprevir therapy in chronic hepatitis patient having dual 
infection with hepatitis $B$ and $C$ viruses. Kanzo 2015; 56:422-27

28. Wang C, Ji D, Chen J, Shao Q, Li B, Liu J. Hepatitis due to reactivation of hepatitis $B$ virus in endemic areas among patients with hepatitis $\mathrm{C}$ treated with direct-acting antiviral agents. Clin Gastroenterol Hepatol. 2016 Jul 5. pii: S1542-3565(16): 30370-6.

29. Collins JM, Raphael KL, Terry C, Cartwright EJ, Pillai A, AnaniaFA. Hepatitis $B$ virus reactivation during successful treatment of hepatitis $\mathrm{C}$ virus with sofosbuvir and simeprevir. Clin Infect Dis 2015; 61:1304-6.
30. De Monte A, Courjon J, Anty R, Cua E, Naqvi A, Mondain V. Direct- acting antiviral treatment in adults infected with hepatitis C virus: Reactivation of hepatitis $B$ virus coinfection as a further challenge. J ClinVirol 2016; 78:27-30.

31. Lasoff DR, Schneir A. Ventricular dysrhythmias from loperamide misuse. J Emerg Med 2016; 50:508-509.

32. Central Drugs Standard Control Organization, Directorate General of Health Services Ministry of Health and Family Welfare, Government of India, Feb 1st 2012, http://cdsco.nic.in/index.html

\section{How to cite this article:}

Sulfath T S et al., Drug safety alerts by FDA and CDSCO in 2016: a recent review \& a study of its implementation in practice. Int. J. Adv. Pharm. Biotech., 2018; 4(1): 1-9. 